\title{
Research on the Evaluation of Urban Modernization Management in Tong Zhou Sub-center in Beijing
}

\author{
Wei LIU ${ }^{1, a}$, Shu-xia LEI ${ }^{2, b}$, Chen-yu LIU ${ }^{3, c}$ \\ ${ }^{1}$ School of Business, North China Institute of Science and Technology, Beijing, China \\ ${ }^{2}$ Beijing Research for Science of Science, Beijing, China \\ ${ }^{3}$ School of Economics and Management, Chongqing University of Posts and Telecommunications, \\ Chongqing, China \\ alwbj0506@163.com, bleishuxia2000@163.com, czhangshiyun@vip.sina.com
}

\begin{abstract}
Key words: Urban sub-center; urban modernization; modernization management; innovation of urban management

Abstract: This thesis chooses the evaluation index of city modernization, strategic deployment and economic development coordination, and the city is the present and future development of the society, environment, economic strength and people's quality of life to adapt, is composed of a series of interrelated and relatively independent and mutually complementary organic whole formed index. The authors use the statistical index according to the principle, "in 2015 2014, the Beijing Municipal Bureau of Statistics Yearbook" etc.. Analysis of the 2015 Beijing Tongzhou sub-center of the basic realization of modernization to realize all kinds of index, pointing out that Tongzhou District currently exists in the economic development, technological innovation, social progress and the quality of people's livelihood and sustainable development of the advantages and disadvantages of Tongzhou District should focus on strengthening the key aspects of economic development, social progress and sustainable development and improvement.
\end{abstract}

\section{Introduction}

The construction of the Beijing Tongzhou sub-center of city modernization evaluation index system is based on the construction of "Beijing new city" as the goal, to improve the quality and efficiency of sub center of economic growth, to improve people's living standards and people-oriented as the fundamental starting point to the institutional innovation and scientific and technological progress as the driving force, to enhance the development of comprehensive coordination sustainability; The author adhere to the construction of sub center city reality from the Beijing of Tongzhou District, adhere to the urban and rural areas, with the industrialization and urbanization and city to promote industrialization, accelerating urban-rural integration and modernization, the construction of new Tongzhou comprehensive coordinated and sustainable development, seize the favorable position in the pattern of regional development, the establishment of a higher reference and the pursuit of the goal the author insists; strengthen institutional innovation, strengthen scientific and technological innovation, and actively promote the city social management innovation Efforts should be made to create a new situation in the scientific development of sub - centers in Beijing and Tongzhou District and contribute to the modernization of Beijing[1].

\section{Principle of design index system}

To construct the evaluation index system of the modernization of the Tong Zhou District sub center city of Beijing, we should draw lessons from the experience of the sub centers of our country, especially those of the developed countries, combining the actual situation of Tong Zhou District. Specific should follow the following principles:

-Scientific and oriented. The author chooses the index system, need to grasp the connotation and essence of city management modernization and the general rules of the basic requirements, scientific framework, content, standards and evaluation methods of design index; new idea to 
effectively guide and encourage vice center departments to establish scientific development, explore new ways of scientific development, grasp the direction of the work, clear work the focus, to promote sound and rapid economic and social development.

-Strategic and operational. The author selected the development of key indicators with overall and long-term significance of Beijing Tongzhou District sub center of economy and society, which can reflect the overall level of the Beijing sub center of Tongzhou District modernization and comprehensive management; to fully consider the statistical data collection, quantification, comparison, with a few key indicators reflect the typical characteristics of Beijing Tongzhou District sub center of city modernization $[2,3]$.

- Sustainability and development. The urban modernization index system chosen by the author is an organic whole composed of a series of interrelated, relatively independent and complementary indicators [4]. The evaluation index of urban management modernization should be coordinated with the economic development strategy, and should be adapted to the urban environment, the economic strength and the quality of life and the ecological environment of the people [5]. The evaluation index of urban management modernization should also reflect the sustainable development principle of population, resources, environment, economy and society coordinated development[6].

- Realism and internationalization. The author selected the Beijing sub central city modernization index system, in line with the actual development of Tongzhou and development goals. At the same time, we should draw on the international standards of modern American expert Alex Kerr and [7].

\section{Index system and evaluation of modernization degree of Tongzhou sub-center city in Beijing}

\section{Index selection}

According to the above design principles and concepts, Beijing Tongzhou sub-center of the basic realization of modernization index system was set as: Set 1 first level indicators (general composite indicators), That is, the sub - center of Beijing and Tongzhou realize basically the comprehensive realization index of modernization, Set 35 three level indicators. Among them, Set 5 two level indicators: Economic development, Scientific-technological innovation. Social progress, People's livelihood quality, Sustainable development. See Table 1 for the 35 grade three indicators, see Table 1

\section{Data collection}

First of all, according to the Beijing set much starker choices-and graver consequences-in planning and decomposition of index system, Tong Zhou district, "much starker choices-and graver consequences-in" period for national economic and social development planning, and urban modernization evaluation set the target value of Tong Zhou zone in 2020; According to the Beijing municipal bureau of statistics, 2014, 2015, 2015, the Tong Zhou district in 2015 and "twelfth five-year" period statistics bulletin of the national economy and social development and the statistical yearbook of science and technology and so on, to determine the implementation value of Beijing Tong Zhou district 2015 (Chart 1).

\section{Integrated computation}

- Calculate three level index index. Formula: $I_{\mathrm{i} j}=\frac{\mathrm{q}_{\mathrm{j}}}{\mathrm{q}_{\mathrm{j}}^{\prime}} \times 100 \%$

- Calculate two level index index. Formula:

$$
\bar{K}_{\mathrm{i}}=\frac{\sum \omega_{\mathrm{ij}} I_{\mathrm{i} j}}{\sum \omega_{\mathrm{i} j}}
$$

$$
\bar{K}=\frac{\sum \omega_{i} \overline{K_{i}}}{\sum \omega_{i}}
$$

In the formula mentioned above, $q_{j}$. expression the real value of a three-level indicators In 2015, $q_{j}$. $I_{\mathrm{ij}}$ expression the $i$ th a secondary index of the first $j$ a three-level index, $\bar{K}_{\mathrm{i}}$ expression the $i$ th a 
secondary index, $i=1,2, \ldots 6, j=1,2, \ldots .36, \bar{K}$ expression one class index.

The first level index $\bar{K}$ is qualitatively divided into 5 grades, namely excellent, good, medium, passing and failing [8]. According to the above formula, the comprehensive indexes of the modernization of the Tongzhou sub central cities in Beijing in 2015, and the scores of the two and three levels are calculated. Table 1. As shown in table 1.

Data sources: Beijing municipal bureau of statistics, 2014, 2015, the Tong Zhou district in 2015 and "twelfth five-year" period statistics bulletin of the national economy and social development. Note (31), COD, sulfur dioxide, carbon dioxide, ammonia nitrogen and nitrogen oxides emissions reduction rate of 10.0/12 / / 8/10 respectively.

\section{Analysis and evaluation results}

Evaluate the results of the first level comprehensive indicators: in 2015, the Beijing Tongzhou sub-center basically achieved modernization indicators, the comprehensive evaluation value was $78.56 \%$, the evaluation was medium, close to a good level, see table 1.

Evaluation of two indicators of the results: 2015 Beijing Tongzhou city deputy center modern 5 level two indexes of implementation, implementation of the evaluation of the economic development of the value of $69.71 \%, 67.71 \%$ and $68.26 \%$, the sustainable development of social progress, the three evaluation indicators for the pass, the three index is affected in 2015 Beijing Tongzhou city deputy center the modernization level of the degree of realization. The achievement of scientific and technological innovation is $75.77 \%$, the evaluation is medium, the quality of people's livelihood is $92.12 \%$, and the evaluation is excellent. This shows that the quality of the people's livelihood in Tongzhou has reached a high level, while the level of scientific and technological innovation has reached a moderate level and has not yet reached a good level. 
Table 1 Beijing Tongzhou sub-center basically achieved modernization indicators in 2015

\begin{tabular}{|c|c|c|c|c|c|c|c|c|c|}
\hline index & $\begin{array}{l}2015 \\
\text { value }\end{array}$ & $\begin{array}{c}\text { target } \\
2020\end{array}$ & $\begin{array}{l}\text { We } \\
\text { ight }\end{array}$ & $\begin{array}{l}\text { Specif } \\
\text {-ic } \\
\text { value }\end{array}$ & indicator & $\begin{array}{l}2015 \\
\text { value }\end{array}$ & $\begin{array}{l}\text { target } \\
2020\end{array}$ & $\begin{array}{l}\text { wei } \\
\text { ght }\end{array}$ & $\begin{array}{l}\text { Specif } \\
\text {-ic } \\
\text { value }\end{array}$ \\
\hline 1. Economic development (5) & & & 20 & 69.87 & $\begin{array}{l}\text { (18) per ten thousand bus ownership } \\
\text { (standard) }\end{array}$ & 3.25 & 15 & 2 & 21.67 \\
\hline (1) the per capita GDP (\$) & 0.66 & 1.3 & 4 & 50.77 & $\begin{array}{l}\text { (19) per ten thousand bus ownership } \\
\text { (standard) }\end{array}$ & 89.87 & 90 & 2 & 99.86 \\
\hline $\begin{array}{l}\text { (2) the local general budget revenue per } \\
\text { capita (ten thousand yuan) }\end{array}$ & 0.51 & 1.3 & 4 & 40.0 & $\begin{array}{l}\text { (20) Incidence of criminal cases per } \\
\text { million people }\end{array}$ & 9.55 & 8 & 2 & 83.77 \\
\hline $\begin{array}{l}\text { (3) the new high-tech product output } \\
\text { value of industrial output value } \\
\text { proportion }(\%)\end{array}$ & 61.6 & 70 & 4 & 88.0 & $\begin{array}{l}\text { (21) public civilization index (cities } \\
\text { ranking than) }(\%)\end{array}$ & 69.06 & 75 & 2 & 92.08 \\
\hline (4) the service industry added value of GDP $(\%)$ & 4.5 & 6 & 3 & 75.0 & 4. The people's livelihood (8) & & & 20 & 92.26 \\
\hline $\begin{array}{l}\text { Among them: the added value of } \\
\text { cultural industry: a share of GDP }(\%)\end{array}$ & 5.21 & 6 & 1 & 86.83 & $\begin{array}{l}\text { (22) of urban and rural residents per } \\
\text { capita income (ten thousand \$) }\end{array}$ & $\begin{array}{l}3.8 / 2 \\
.2\end{array}$ & $\begin{array}{c}6.0 / 3 \\
5\end{array}$ & 3 & 63.1 \\
\hline $\begin{array}{l}\text { The added value of tourism industry of } \\
\text { GDP }(\%)\end{array}$ & 5.69 & 6.0 & 1 & 94.83 & (23)Engel's coefficient (\%) & 28.4 & 26.5 & 3 & 100.0 \\
\hline $\begin{array}{l}\text { (5) the efficient agricultural proportion } \\
(\%)\end{array}$ & 58.8 & 64 & 3 & 91.88 & $\begin{array}{lcl}(24) & \text { residents } & \text { registered } \\
\text { unemployment rate }(\%) & \\
\end{array}$ & 1.99 & 2.0 & 3 & 99.50 \\
\hline 2. Science technology (6) & & & 20 & 75.77 & $\begin{array}{l}\text { (25) of urban and rural residents } \\
\text { basic social insurance coverage (\%) }\end{array}$ & 98.9 & 99 & 3 & 99.90 \\
\hline $\begin{array}{l}\text { (6) research and development spending in the } \\
\text { whole society GDP proportion (\%) }\end{array}$ & 2.5 & 3.0 & 3 & 83.33 & $\begin{array}{l}\text { (26) urban per capita housing area } \\
\text { (m2) }\end{array}$ & 34.6 & 35 & 2 & 98.86 \\
\hline $\begin{array}{l}\text { Among them: enterprise R\&D spending } \\
\text { accounts for the whole society the } \\
\text { proportion of } R \& D(\%)\end{array}$ & 40 & 90 & 2 & 44.44 & $\begin{array}{l}\text { (27) enjoy social endowment service } \\
\text { number accounts for the total } \\
\text { proportion }(\%) \text { in the elderly }\end{array}$ & 10 & 10 & 2 & 100.0 \\
\hline $\begin{array}{l}\text { (7) science and technology progress } \\
\text { contribution rate }(\%)\end{array}$ & 60 & 60 & 3 & 100.0 & $\begin{array}{l}\text { (28) average life expectancy (years } \\
\text { old) }\end{array}$ & 80 & 80 & 2 & 100.0 \\
\hline (8) patent grant (a/ten thousand) & 31.09 & 55 & 3 & 56.53 & $\begin{array}{l}\text { (29) permanent population size (ten } \\
\text { thousand) }\end{array}$ & 160 & 200 & 2 & 80.00 \\
\hline $\begin{array}{l}\text { (9) number talent per ten thousand } \\
\text { people (people) }\end{array}$ & 3149 & 3500 & 3 & 89.97 & 5.Sustainable development (6) & & & 20 & 68.26 \\
\hline $\begin{array}{l}\text { (10)Human capital investment as a share } \\
\text { of GDP (10) }(\%)\end{array}$ & 14 & 17 & 3 & 82.35 & $\begin{array}{l}\text { (30) ten thousand yuan GDP energy } \\
\text { consumption decreased rate }(\%)\end{array}$ & 0.36 & 0.27 & 3 & 100.0 \\
\hline $\begin{array}{l}\text { (11) venture capital scale (one hundred } \\
\text { million yuan) }\end{array}$ & 95 & 150 & 3 & 63.33 & $\begin{array}{l}\text { (31) COD, sulfur dioxide, carbon } \\
\text { dioxide, ammonia nitrogen and } \\
\text { nitrogen oxides emissions reduction } \\
\text { rate }\end{array}$ & 12.7 & 10 & 3 & 78.74 \\
\hline 3. Social progress (10) & & & 20 & 67.87 & $\begin{array}{l}\text { (32) unit inventory construction land } \\
\text { GDP productivity (ten thousand } \\
\text { yuan/ha) }\end{array}$ & $\begin{array}{c}4966 . \\
9\end{array}$ & 7000 & 3 & 70.96 \\
\hline (12) the level of urbanization & 64.23 & 75 & 2 & 85.64 & $\begin{array}{l}\text { (33) land, urban greening forest } \\
\text { coverage rate }(\%)\end{array}$ & $\begin{array}{l}55.01 \\
/ 28.4 \\
\end{array}$ & $56 / 33$ & 2 & 92.98 \\
\hline $\begin{array}{l}\text { (13) of urban and rural public service } \\
\text { expenditure of fiscal expenditure } \\
\text { proportion (\%) }\end{array}$ & 66.5 & 70 & 2 & 95.0 & $\begin{array}{l}\text { (34) urban sewage concentrated rate } \\
(\%)\end{array}$ & 62.63 & 95 & 2 & 65.93 \\
\hline $\begin{array}{l}\text { (14) new Labour education fixed } \\
\text { number of year (year) }\end{array}$ & 14 & 15.5 & 2 & 90.32 & $\begin{array}{l}\text { Among them, hazard-free treatment } \\
\text { rate of urban and rural living garbage } \\
(\%)\end{array}$ & 99.14 & 100 & 2 & 99.14 \\
\hline $\begin{array}{l}\text { (15) higher education gross enrollment } \\
\text { ratio }(\%)\end{array}$ & 60 & 65 & 2 & 92.31 & $\begin{array}{lcc}35) & \text { environmental } & \text { quality } \\
\text { comprehensive index (points) } & \\
\end{array}$ & 90 & 90 & 3 & 100.0 \\
\hline $\begin{array}{l}\text { (16) per capita public cultural and } \\
\text { sports facilities area }(\mathrm{m} 2)\end{array}$ & 0.03 & 0.18 & 2 & 16.67 & $\begin{array}{l}\text { The realization degree of composite } \\
\text { index }\end{array}$ & - & - & 100 & 78.56 \\
\hline $\begin{array}{l}\text { (17) number doctors per one thousand } \\
\text { people (people) }\end{array}$ & 3.74 & 4 & 2 & 93.50 & & & & & \\
\hline
\end{tabular}

The results show that in the Tongzhou District economic development, sustainable development and social progress of the implementation of only in the early modernization, namely pass level, especially the lowest degree of social progress of modern economic development, less than 2 percentage points. This shows that in the future construction of Beijing Tongzhou sub-center, efforts should be made to strengthen economic development, social progress and sustainable development.

Evaluation of three indicators of the results, divided into the following five categories:

- Excellent indicator: tourism industry accounted for the proportion of GDP evaluation value is $94.83 \%$, the proportion of agriculture, $91.88 \%$; the contribution rate of science and technology realization degree is $100 \%$. The urban and rural public service expenditures accounted for the proportion of fiscal expenditure is $95 \%$, The new labor education $90.32 \%$, higher education gross enrollment rate $92.31 \%$, Doctors per thousand people $93.50 \%$, Internet penetration rate achieved 
$99.86 \%$, the degree of public civilization index $92.08 \%$. There are six quality of life index, the Engel coefficient is $100 \%$, the registered unemployment rate $99.5 \%$, urban and rural residents basic social insurance coverage rate $99.9 \%$, urban per capita housing area $98.83 \%$, enjoy social pension services accounted for the proportion of the total number of elderly people $100 \%$, the average life expectancy $100 \%$. The yuan GDP energy consumption fell rate $100 \%$ city land, afforestation, the forest coverage rate to achieve degrees $92.98 \%$, the degrees to achieve comprehensive index of environmental quality $100 \%$.

- Good indicator: The high and new technology product output value accounted of the total industrial output value over the scale is $88.0 \%$, the cultural industry added value of a share of GDP $86.83 \%$. The whole society R\&D spending realization degree is $83.33 \%$, the proportion of GDP in every ten thousand people have talent for $89.97 \%$, human capital investment of GDP to achieve degrees $82.35 \%$; The realization degree of urbanization is $85.64 \%$, per ten thousand criminal cases ratings achieved $83.77 \%$; The resident population scale realization degree is $80.0 \%$.

- Medium target. The service industry added value of GDP is $75.0 \%$. The realization degree of urbanization is $85.64 \%$, Per ten thousand criminal cases ratings realization degree is $83.77 \%$. COD, sulfur dioxide, carbon dioxide, ammonia nitrogen and nitrogen oxides emissions reduction rate achieved is $78.74 \%$, an inventory construction land output achieved GDP $70.96 \%$.

- Passing index: venture investment capital scale degrees is $63.33 \%$. The urban and rural residents per capita income achieved is $62.19 \%$. The urban sewage concentrated rate achieved is $65.93 \%$.

- Failing mark. The per capita GDP realization degree is $50.43 \%$, local general budget revenue per capita $39.54 \%$. The enterprise research and development of the whole society the proportion of $\mathrm{R} \& \mathrm{D}$ investment realization degree is only $44.44 \%$, the patent grant is $56.53 \%$. The realization degree of public cultural and sports facilities area per is $15.0 \%$, per ten thousand bus ownership realization degree $21.67 \%$.

As these three indicators are too low, they drag down the implementation of the whole two level and first level indicators. This requires Tongzhou District to strengthen economic development, technological innovation, social progress and the quality of people's livelihood and sustainable development of the work, especially should vigorously strengthen economic development, social progress and sustainable development of backward.

\section{Conclusion}

- The implementation of economic development degree, vice center of Beijing Tong Zhou economic development level is low, because GDP per capita GDP as well as the relative index is low, local general budget revenue per capita is less than forty percent of the standard; The added value of service industry of GDP still has a lot of value and development space.

- Technological innovation ability is low. Beijing Tongzhou sub-center of enterprise R \& D investment accounted for the proportion of investment in research and development of the whole society is too low, the enterprise has not become the main body of market development, regional innovation capacity is still insufficient, but also regional venture capital scale is still small, and government funds play a leading role, but the lack of guide.

- Social progress needs to be improved. Tongzhou District is in the leading position in the part of basic public services and modern communication and Internet technology, on the whole it can be said that Tongzhou District has basically reached the level of moderately developed countries, but Tongzhou District is still a serious lack of infrastructure, but also the social management upgrade and great development space.

- The quality of people's livelihood is still low. Tongzhou District in the people's life, social security has basically reached the level of moderately developed countries, but the per capita income of rural residents in Tongzhou District relative to basically achieve modernization degree, is still very low, to a certain extent affected the quality of the quality of people's livelihood. 
- The level of sustainable development is stronger. In addition to focus on urban sewage treatment is still in a backward level, the Tongzhou sub-center in the yuan GDP energy consumption decreased rate, city greening, forest coverage, land environmental quality comprehensive index and walked to the front of city construction.

\section{Acknowledgement}

This research was financially supported by Beijing Research for Science of Science. This research was financially supported by the Fundamental Research Funds for the Central Universities (No. 3142014014/3142015105).

\section{References}

[1] Tong Zhou district development plan, http://stats.bjtzh.gov.cn/n5244911/n7978319/index.html.

[2] Ji jianlin. Research on thinking about the problems of basic modernization indicator system [J]. Jiang hai Review,5,15 2011-18.

[3] Mao hanying. Index system of sustainable development in shandong province [J]. Journal of geographical research, 1996,4,22-25.

[4] Zhu yingming, Yao shimou. Issues related to urban modernization indicator system research in China [J]. Journal of human geography, 2000, 8.

[5] Zhu qingfang. World cities social indicators compared [M]. Beijing: China city press, 1997, 1 to 13.

[6]China's agenda 21, China in the 21st century, population, environment and development white paper [R]. Beijing: China environmental science press, 1995, 1.

[7]Wu hanguang. Our country well-off living standard measurement scale and standard [J]. China population, resources and environment, 1995, 5 (2) : 57 to 60 .

[8]Liu wei, Zhang shiyun. Beijing urban and rural economic and social integration evaluation quantitative research [J]. Ecological economy, 2009, 8 (2) : 60-63. 